\title{
ECONOMIC ANALYSIS OF CACTUS PEARS BIO-FUNCTIONAL, MEDICINAL, NUTRACEUTICAL AND COSMETIC PROPERTIES (PÓSTER)
}

\author{
Lucia Andreu ${ }^{\mathrm{a}}$, Marina Cano $^{\mathrm{a}}$, Luis Noguera ${ }^{\mathrm{a}}$, Leontina Lipan ${ }^{\mathrm{a}}$, Ángel Carbonella, Beatriz

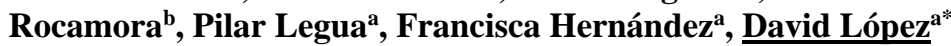

\begin{abstract}
${ }^{a}$ Centro de investigación e innovación agroalimentaria y agroambiental (CIAGRO-UMH). Escuela Politécnica Superior de Orihuela (EPSO-UMH). Ctra. Beniel km 3.2. 03312 (Orihuela). Universidad Miguel Hernández de Elche. Spain

${ }^{b}$ Departamento de Producción y Sanidad Animal, Salud Pública Veterinaria y Ciencia y Tecnología de los Alimentos. Universidad Cardenal Herrera-CEU. C. Tirant Lo Blanc, 7. Alfara del Patriarca, Valencia Spain

*Author for correspondance: david.lopez@umh.es
\end{abstract}

Keywords: Opuntia, non-food uses, Spain, economic analysis

\section{Introduction and objectives}

There is a vast potential for non-food uses of cactus pear, exploiting its bio-functional, medicinal, nutraceutical and cosmetic properties (El-Mostafa et al., 2014). Chemical and nutritional components of prickly pear fruit have already been studied (Andreu-Coll et al., 2019; Andreu et al., 2017; El Kossori et al., 1998; Gurrieri et al., 2000; Mena et al., 2018). Furthermore, it has been shown that cactus pear fruit extract holds antiulcerogenic, anti-inflammatory, antidiabetic, antioxidant, anticancer, neuroprotective, hepatoprotective and antiproliferative activities (Allegra et al., 2014; Antunes-Ricardo et al., 2015; Kuti, 2004; Park et al., 2001). Cactus pears have also been reported as a good source for red and yellow food coloring agents (Castellar et al., 2003; Esatbeyoglu et al., 2015; Fernández-López et al., 2012, 2002; Fernández-López et al., 2001; García-Cayuela et al., 2019). There has been also research regarding cactus pear as a source of bioactive compounds for nutrition, health and disease (Ayadi et al., 2009; Esatbeyoglu et al., 2015; Melgar et al., 2017; Nuñez-López et al., 2013; Pinedo-Espinoza et al., 2017). However, there is not an economic analysis of the value of these properties linked to the cactus pear production. So, the objective of this work is to explore the economic opportunities of Opuntia cultivation in Spain regarding non-food uses of cactus pear (exploiting its bio-functional, medicinal, nutraceutical and cosmetic properties).

\section{Materials and Methods}

A revision of literature has been made to establish the quantity of components with bio-functional, medicinal, nutraceutical and cosmetic properties that cactus pear holds. Market prices of these compounds have been obtained through a questionnaire among main producers. Then, an estimation of the quantities that could be obtained from a hectare of cactus pear in Spain has been calculated considering the production data obtained in the questionnaire carried out to producers.

\section{Results}

Table 1 shows the average content of bio-functional, medicinal, nutraceutical and cosmetic components in cactus pears according to the existing scientific literature. Extractions are usually done with methanol and water (different proportions according to the procedure) and analyzed by HPLC. Table 2 summarizes current prices for the main bio-functional, medicinal, nutraceutical and cosmetic components, as declared by main commercial companies. Finally, Table 3 shows the normal weights and average prices of biofunctional, medicinal, nutraceutical and cosmetic components sold in the market compared with the average quantity (in micrograms) of these components present in a gram of cactus pear dry weight.

Table 1. Average quantity of bio-functional, medicinal, nutraceutical and cosmetic components in cactus pears (quantities are expressed in $\mu g g^{-1} d w$ )

$\begin{array}{ccc}\text { Compound } & \begin{array}{c}\text { Average content }(\mu \mathrm{g} \\ \left.\mathrm{g}^{-1} \mathrm{dw}\right)\end{array} & \text { References } \\ & \end{array}$




\begin{tabular}{|c|c|c|}
\hline Kaempferol & 34.04 & $\begin{array}{l}\text { El-Mostafa et al. (2014), García-Cayuela et } \\
\text { al. (2019), Mena et al. (2018), Tesoriere et al. } \\
(2005)\end{array}$ \\
\hline Myrcetin & 65 & Mena et al. (2018) \\
\hline Isorhamnetin (and derivatives) & 590 & $\begin{array}{l}\text { El-Mostafa et al. (2014), García-Cayuela et } \\
\text { al. (2019), Mena et al. (2018), Yeddes et al. } \\
\text { (2013) }\end{array}$ \\
\hline Luteolin & 8.4 & El-Mostafa et al. (2014) \\
\hline Ferulic acid (and derivatives) & 1050 & Mena et al. (2018) \\
\hline Catechin & 50 & Mena et al. (2018) \\
\hline Guaiacyl(t8-O-4)guaiacyl-hexoside & 105 & Mena et al. (2018) \\
\hline $\begin{array}{l}\text { Guaiacyl(8-O-4)syrinigyl(8- } \\
\text { 8)guaiacyl-hexoside }\end{array}$ & 60 & Mena et al. (2018) \\
\hline Syrinigyl(t8-O-4)guaiacyl & 60 & Mena et al. (2018) \\
\hline Sinapic acid (and derivatives) & 1140 & Mena et al. (2018) \\
\hline Quercetin (and derivatives) & 91.1 & $\begin{array}{l}\text { El-Mostafa et al. (2014), García-Cayuela et } \\
\text { al. (2019), Mena et al. (2018), Yeddes et al. } \\
(2013)\end{array}$ \\
\hline Narigin (and derivatives) & 75 & Mena et al. (2018) \\
\hline Syringaresinol & 105 & Mena et al. (2018) \\
\hline 4-Hydroxy-benzoic acid & 665 & García-Cayuela et al. (2019) \\
\hline Piscidic acid & 18865 & García-Cayuela et al. (2019) \\
\hline Betaxantins & 196 & $\begin{array}{l}\text { Cano et al. (2017); García-Cayuela et al. } \\
\text { (2019), Tesoriere et al. (2005) }\end{array}$ \\
\hline Betacyanins & 328 & $\begin{array}{l}\text { Albano et al. (2015); Cano et al. (2017), } \\
\text { García-Cayuela et al. (2019) }\end{array}$ \\
\hline
\end{tabular}

Table 2. Average current prices and commercial quantities for the main bio-functional, medicinal, nutraceutical and cosmetic components

\begin{tabular}{lcc}
\hline \multicolumn{1}{c}{ Compound } & Weight & Average price (€) \\
\hline Kaempferol (520-18-3) & $20 \mathrm{mg}$ & 213.68 \\
Myricetin (529-44-2) & $20 \mathrm{mg}$ & 238.11 \\
Rhamnetin (90-19-7) & $10 \mathrm{mg}$ & 198.42 \\
Fisetin (528-48-3) & $10 \mathrm{mg}$ & 195.37 \\
Isorhamnetin (480-19-3) & $10 \mathrm{mg}$ & 204.53 \\
Myrcene (123-35-3) & $100 \mathrm{mg}$ & 134.32 \\
Galangin (548-83-4) & $20 \mathrm{mg}$ & 225.89 \\
Kaempferide (491-54-3) & $10 \mathrm{mg}$ & 177.05 \\
Luteolin (491-70-3) & $10 \mathrm{mg}$ & 189.26 \\
Ferulic Acid (537-98-4) & $1 \mathrm{~g}$ & 134.32 \\
Gossypetin (489-35-0) & $10 \mathrm{mg}$ & 265.58 \\
4-Coumaric acid (501-98-4) & $1 \mathrm{~g}$ & 134.32 \\
3-Coumaric acid (14755-02-3) & $1 \mathrm{~g}$ & 134.32 \\
2-Coumaric acid (614-60-8) & $1 \mathrm{~g}$ & 134.32 \\
(+)- Catechin (154-23-4) & $10 \mathrm{mg}$ & 186.21 \\
Morin (480-16-0) & $20 \mathrm{mg}$ & 195.37 \\
\hline
\end{tabular}

Table 4 presents the value in $€$ of a g of cactus plant (dw, dry weight) according to its content of biofunctional, medicinal, nutraceutical and cosmetic components. 
According to Butera et al. (2002), El-Mostafa et al. (2014), García-Cayuela et al. (2019), Mena et al. (2018), Tesoriere et al. (2005), the average quantity of water of cactus pear is $80 \%$. The cactus pear average production per ha is $234 \mathrm{tha}^{-1}$ (ranging from 273 to $195 \mathrm{t} \mathrm{ha}^{-1}$ ) in Spain.

Table 3. Average quantities and average prices of several components in the marketplace compared with the average quantity (in micrograms) of these component present in a gram of cactus pear dry weight

\begin{tabular}{|c|c|c|c|c|}
\hline \multicolumn{3}{|c|}{ MARKET PLACE } & \multicolumn{2}{|c|}{ CACTUS PEAR } \\
\hline Component & $\begin{array}{l}\text { Average } \\
\text { price }(€)\end{array}$ & $\begin{array}{l}\text { Average } \\
\text { quantity }\end{array}$ & Component & $\begin{array}{l}\text { Average quantity } \\
\quad\left(\mu \mathrm{g} \mathrm{g}^{-1} \mathrm{dw}\right)\end{array}$ \\
\hline Kaempferol (520-18-3) & 213.68 & $20 \mathrm{mg}$ & Kaempferol & 34.04 \\
\hline Myrcetin (529-44-2) & 238.11 & $20 \mathrm{mg}$ & Myrcetin & 65 \\
\hline Isorhamnetin (480-19-3) & 204.53 & $10 \mathrm{mg}$ & Isorhamnetin (and derivatives) & 589.87 \\
\hline Luteolin (491-70-3) & 189.26 & $10 \mathrm{mg}$ & Luteolin & 8.4 \\
\hline Ferulic Acid (537-98-4) & 134.32 & $1 \mathrm{~g}$ & Ferulic acid (and derivatives) & 1050 \\
\hline Catechin (154-23-4) & 186.21 & $10 \mathrm{mg}$ & Catechin & 50 \\
\hline
\end{tabular}

Table 4. Value of each g of cactus (dry weight) according to its composition

\begin{tabular}{lccc}
\hline \multicolumn{1}{c}{ Component } & Average price $\left(\boldsymbol{\epsilon} \boldsymbol{\mu g}^{-\mathbf{1}}\right)$ & $\begin{array}{c}\text { Average content }(\boldsymbol{\mu g}) \text { in } \mathbf{1} \mathbf{~ d w} \\
\text { of cactus pear }\end{array}$ & $\begin{array}{c}\text { Value }(\boldsymbol{\epsilon}) \text { of } \mathbf{1} \mathbf{g} \mathbf{d w} \\
\text { of cactus pear }\end{array}$ \\
\hline kaempferol (520-18-3) & 0.010684 & 34.04 & 0.36 \\
Myrcetin (529-44-2) & 0.011906 & 65 & 0.77 \\
Isorhamnetin (480-19-3) & 0.020453 & 589.87 & 12.06 \\
Luteolin (491-70-3) & 0.018926 & 8.4 & 0.16 \\
Ferulic Acid (537-98-4) & 0.134320 & 1050 & 141.04 \\
$(+)-$ Catechin (154-23-4) & 0.018621 & 50 & 0.93 \\
\hline
\end{tabular}

\section{Conclusions}

Quantities of compounds with bio-functional, medicinal, nutraceutical and cosmetic properties in Opuntia have been analysed. Average quantities and average prices of these highly-demanded components sold in the market compared with the average quantity (in $\mu \mathrm{g}$ ) of these components present in $1 \mathrm{~g}$ of dried cactus pear has been presented. A further research should look at the cost of obtaining these compounds. These processes and their costs are dependent on the type of plant material and compound to be extracted but there are no studies on these factors in prickly pear. It seems that obtaining these compounds could be a way of increasing profitability of cactus pear production and creating jobs and value in rural areas.

\section{References}

Albano, C., Negro, C., Tommasi, N., Gerardi, C., Mita, G., Miceli, A., de Bellis, L. and Blando, F., (2015(. Betalains, phenols and antioxidant capacity in cactus pear [Opuntia ficus-indica (L.) mill.] fruits from Apulia (South Italy) genotypes. Antioxidants 4: 269-280.

Allegra, M., Ianaro, A., Tersigni, M., Panza, E., Tesoriere, L. and Livrea, M.A., (2014). Indicaxanthin from Cactus Pear Fruit Exerts Anti-Inflammatory Effects in Carrageenin-Induced rat pleurisy. The Journal of Nutrition 144 (2): 185-192. 
Andreu-Coll, L., Cano-Lamadrid, M., Sendra, E., Carbonell-Barrachina, Á., Legua, P. and Hernández, F., 2019. Fatty acid profile of fruits (pulp and peel) and cladodes (young and old) of prickly pear [Opuntia ficus-indica (L.) Mill.] from six Spanish cultivars. J. Food Compos. Anal. 84, 103294.

Andreu, L., Nuncio-Jáuregui, N., Carbonell-Barrachina, Á.A., Legua, P. and Hernández, F. (2017). Antioxidant properties and chemical characterization of Spanish Opuntia ficus-indica Mill . cladodes and fruits. J. Sci. Food Agric 98: 1566-1573

Antunes-Ricardo, M., Gutiérrez-Uribe, J.A., López-Pacheco, F., Alvarez, M.M., and Serna-Saldívar, S.O., (2015). "In vivo anti-inflammatory effects of isorhamnetin glycosides isolated from Opuntia ficusindica (L.) Mill cladodes". Ind. Crops Prod 76: 803-808

Ayadi, M.A., Abdelmaksoud, W., Ennouri, M. and Attia, H. (2009). "Cladodes from Opuntia ficus indica as a source of dietary fiber: Effect on dough characteristics and cake making". Ind. Crops Prod 30: 40-47

Butera, D., Tesoriere, L., Di Gaudio, F., Bongiorno, A., Allegra, M., Pintaudi, A.M., Kohen, R. and Livrea, M.A. (2002). "Antioxidant activities of Sicilian prickly pear (Opuntia ficus indica) fruit extracts and reducing properties of its betalains: betanin and indicaxanthin". J. Agric. Food Chem. 50: 68956901

Cano, M.P., Gómez-Maqueo, A., García-Cayuela, T. and Welti-Chanes, J. (2017) "Characterization of carotenoid profile of Spanish Sanguinos and Verdal prickly pear (Opuntia ficus-indica, spp.) tissues". Food Chem. 237: 612-622

Castellar, R., Obón, J.M., Alacid, M. and Fernández-López, J.A. (2003). "Color properties and stability of betacyanins from Opuntia fruit”s. J. Agric. Food Chem. 51: 2772-2776.

El-Mostafa, K., El Kharrassi, Y., Badreddine, A., Andreoletti, P., Vamecq, J., El Kebbaj, M.S., Latruffe, N., Lizard, G., Nasser, B. and Cherkaoui-Malki, M., 2014. "Nopal cactus (Opuntia ficus-indica) as a source of bioactive compounds for nutrition, health and disease". Molecules 19: 14879-14901

El Kossori, R.L., Villaume, C., El Boustani, E., Sauvaire, Y. and Méjean, L. (1998) "Composition of pulp, skin and seeds of prickly pears fruit (Opuntia ficus indica sp.)". Plant Foods Hum. Nutr 52: 263270.

Esatbeyoglu, T., Wagner, A.E., Schini-Kerth, V.B. and Rimbach, G. (2015). "Betanin-A food colorant with biological activity”. Mol. Nutr. Food Res. 59, 36-47.

Fernández-López, J.A. and Almela, L. (2001). "Application of high-performance liquid chromatography to the characterization of the betalain pigments in prickly pear fruits". J. Chromatogr. A, 913: 415-420

Fernández-López, J.A., Giménez, P.J., Angosto, J.M. and Moreno, J.I. (2012). “A process of recovery of a natural yellow colourant from Opuntia fruits". Food Technol. Biotechnol. 50: 246-251.

García-Cayuela, T., Gómez-Maqueo, A., Guajardo-Flores, D., Welti-Chanes, J. and Cano, M.P. (2019”. "Characterization and quantification of individual betalain and phenolic compounds in Mexican and Spanish prickly pear (Opuntia ficus-indica L. Mill) tissues: A comparative study”. J. Food Compos. Anal. 76: 1-13.

Gurrieri, S., Miceli, L., Maria Lanza, C., Tomaselli, F., Bonomo, R.P. and Rizzarelli, E. (2000). "Chemical characterization of sicilian prickly pear (Opuntia ficus indica) and perspectives for the storage of its juice". J. Agric. Food Chem. 48: 5424-5431.

Kuti, J.O., 2004. “Antioxidant compounds from four Opuntia cactus pear fruit varieties". Food Chem. 85: 527-533.

Melgar, B., Dias, M.I., Ciric, A., Sokovic, M., Garcia-Castello, E.M., Rodriguez-Lopez, A.D., Barros, L. and Ferreira, I. (2017). "By-product recovery of Opuntia spp. peels: Betalainic and phenolic profiles and bioactive properties". Ind. Crops Prod. 107: 353-359.

Mena, P., Tassotti, M., Andreu, L., Nuncio-Jáuregui, N., Legua, P., Del Rio, D. and Hernández, F. (2018). "Phytochemical characterization of different prickly pear (Opuntia ficus-indica (L.) Mill.) cultivars and botanical parts: UHPLC-ESI-MSn metabolomics profiles and their chemometric analysis". Food Res. Int. 108: 301-308.

Nuñez-López, M.A., Paredes-López, O. and Reynoso-Camacho, R. (2013). "Functional and hypoglycemic properties of Nopal cladodes (O. ficus-indica) at different maturity stages using in vitro and in vivo tests". J. Agric. Food Chem. 61: 10981-10986.

Park, E.H., Kahng, J.H., Lee, S.H. and Shin, K.H. (2001). “An anti-inflammatory principle from cactus”. Fitoterapia 72: 288-290.

Pinedo-Espinoza, J.M., Aguirre-Mancilla, C.L., Jiménez-Alvarado, R., Raya-Pérez, J.C., Iturriaga, G., Ramírez-Pimentel, J.G. and Hernández-Fuentes, A.D. (2017). "Bioactive compounds and antioxidant activity evolution during the ripening process of 12 opuntia spp. fruit accessions". Emirates J. Food Agric. 29: 138-148. 
Tesoriere, L., Fazzari, M., Allegra, M. and Livrea, M.A. (2005). "Biothiols, taurine, and lipid-soluble antioxidants in the edible pulp of sicilian cactus pear (Opuntia ficus-indica) fruits and changes of bioactive juice components upon industrial processing”. J. Agric. Food Chem. 53: 7851-7855.

Yeddes, N., Chérif, J.K., Guyot, S., Sotin, H. and Ayadi, M.T. (2013). "Comparative study of antioxidant power, polyphenols, flavonoids and betacyanins of the peel and pulp of three Tunisian Opuntia forms". Antioxidants 2, 37-51. 